\title{
Gender Portrayals In Pakistani Television Commercials
}

\author{
Sara Wahid \\ Department of Mass Communication \\ University of Karachi \\ Aazadi Fateh Muhammad \\ Department of Mass Communication \\ Federal Urdu University for Arts, Science \& Technology \\ Fateh Muhammad Burfat \\ Department of Criminology \\ University of Karachi
}

\begin{abstract}
This study is aimed to investigate the gender portrayals in Pakistani television commercials that run on Pakistani television channels. The research is mainly a content analysis, intends to examine the gender representation of male and female in Pakistani television commercials. For this purpose the commercials have been closely investigated considering the male and female role portrayals, demographic focus and main voice over/ narrators. Twenty-five commercials were randomly selected from four broad categories of household products, beauty products, telecommunications and edibles. These four product categories represent those television advertisements that have been given greater exposure (in terms of space allocated / air time) on Pakistani television channels and also enlist in top ten product category in the year 2008. The aforementioned top ten product category list was prepared by Gallup Pakistan and accessed from the Aurora purple book (Pakistani advertising magazine) published by Dawn group of newspapers in 2008. (Gallup Pakistan) The research framework attempts to familiarize the readers with the gender representation in Pakistani television commercials, their similarities and differences in comparison with the existing literature from various countries.
\end{abstract}

Key Words: Portrayal, Gender Analysis, PTV Commercials, Similarities \& Differences

$$
\begin{aligned}
& \text { تلخيص }
\end{aligned}
$$

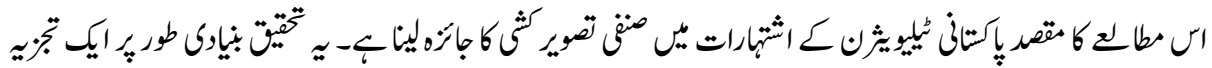

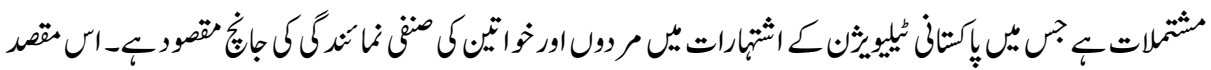

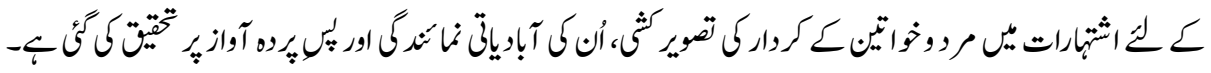

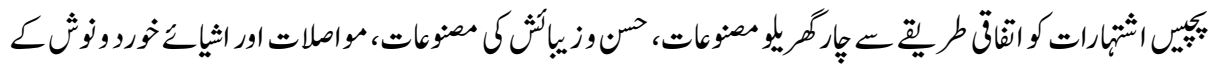

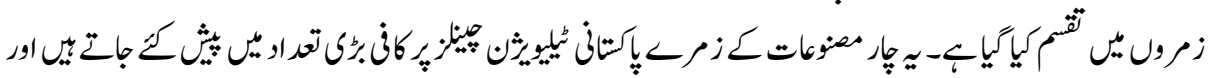




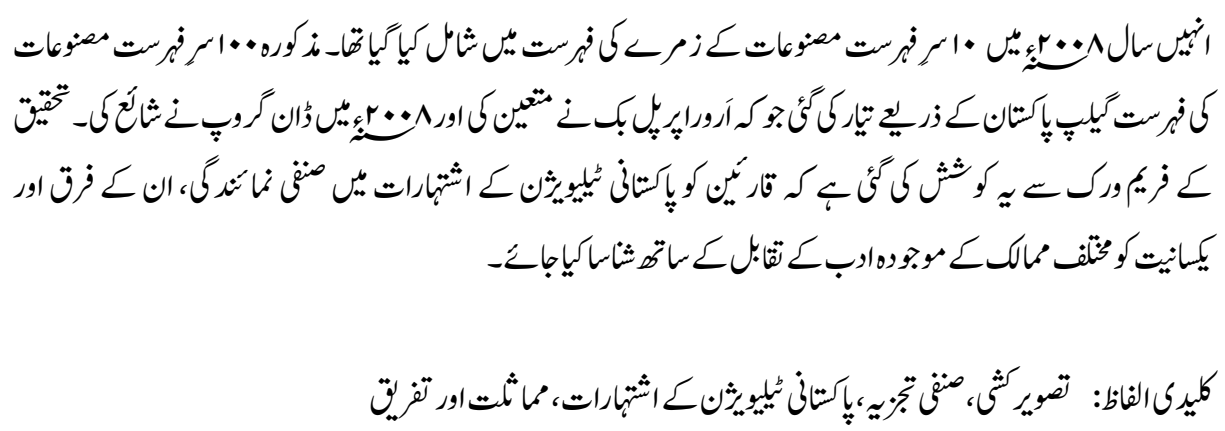

\section{Introduction}

"Gender is a social construct related to masculine and feminine behaviors which are learned" (Mahsud, 2006, p.119). Media performs an active role in telling people how to perceive the societal roles of male and female in the particular social context. It has become an indispensable and yet unavoidable constituent of our social fabric; as we are continuously at the target of media messages from the dawn to dusk. By repetitive portrayal of gender imagery in a particular way; media primarily focuses on the marginalization of gender representation i.e. strengthening the existing inflexible, conventional and biased gender perceptions. (Wood, 1997)

Television presents a reflection of society; we can get the information about any society, its people, their lifestyle and even their thinking patterns through the content featured on their television channels. "According to Gerbner and colleagues, television is responsible for a major 'cultivating' and 'acculturating' process, according to which people are exposed systematically to a selective view of society on almost every aspect of life, a view which tends to shape their beliefs and values accordingly." (McQuail, 2005, p.129)

Given the fact that television has audio-visual attributes, it is believed to manipulate the minds of the viewers more effectively as compared to the other mediums. According to a research television is considered as the preferred information provider due to the fact that it offers unlimited information for the people of diverse age groups (Dominick, 2001). It is therefore notable that television has a vast potential to affect the way people perceive, interpret and behave in certain situations.

As a social being we all are seeker for a new ideas, an exciting place to hang out, stylish outfit to wear at the friends get together, or may be to find a new eating house. It might be a regular grocery visit that takes us to the discovery of new and exciting household products. Seemingly, it is the curious nature of human that we never stop learning and experiencing new things in life. The process of learning is never ending and hence an enriched experience for any individual of any age group. 
Learning takes place when one encounters with several agents of socialization within their social fabric as it seems evident from the term socialization itself that it has been derived from the word social therefore one can assert that it is all about learning those norms, values and behaviors that are socially approved for a particular society. Agents of socialization refer to the individual's social affiliations to the particular groups of people and the communication setting wherein the process of socialization takes place (Giddens, 2006)

Traditionally these agents of socialization are family, educational institutions, peers, religion, work place and community. But over the years media has emerged as a strong socialization agent trying to compete with traditional agents on almost equal front. Apart from other perspectives of socialization, gender socialization is one of the important paradigm on which the researchers have been enthusiastically working since long period of time. This type of socialization rests upon the idea that individual's learn about their expected social roles by observing the experiences of their parents, peers and also by the help of information imparted by media. This process of learning is referred as Gender Socialization (Giddens, 2006). Apart from other socializing agents; media also serve as potent source of disseminating knowledge about different customs and socially approved behaviors in particular social context (Price, 1998).

Provided the efficacy of television in reaching maximum number of audience, advertisers tend to utilize this medium for selling out unlimited products and services to the scattered audience. "Television commercials are hard to escape; some people leave the room during breaks or do not watch the commercials, but the majority of the audience cannot--indeed do not want to close their eyes and ears." (Broadbent, 1979, p.60)

Individuals learns about the wide spread gender based imagery since the time of their childhood. These generalizations are deep seated in the culture of any particular society and transmit to every generations by the traditional agents $f$ social interaction including parents, peers etc. The culture of a particular society provides their individual criteria and way of interpreting various social situations and individual's role portrayal in the given social context. As advertising is supposed to mirrors the prevalent social milieu therefore they also conforms to those generalizations that already prevail in the society (Frith \& Mueller, 2010).

In view of aforementioned significant dimensions of television advertising, it is therefore imperative for the advertisers and communication scholars to understand the role, function and perception of television commercials closely. Of other essential components, gender portrayal is a significant social variable that needs to be explored. Given the significant attributes of television one can imagine how deep impact it can create over the minds of its viewers. 
According to Shrikhande (2003) "It is safe to conclude that stereotypes exist and are a part of our lives. People act according to these stereotypes because stereotypes are considered socially acceptable". Advertising stereotypes can be detrimental as the repetitive exposure increases the acceptance of these subjective interpretations among the masses (Frith \& Mueller, 2010). The contribution of advertising in fostering stereotypical images in the society seems evident from these lines cited by White (2000) that advertising does not only highlight stereotypical portrayals intentionally but it has the ability to quickly get connected with its audience by using previously familiar images.

In view of abovementioned ideas; it can be claimed that stereotypical ideas are generated mostly because it helps to create a relevance factor between the mindset of audience and the message conveyed. It is human psychology that ideas, practices or an issue which seem common and relevant helps individual to understand the upcoming stimuli in a better way. Moreover, it is crucial to realize that the impact of stereotyping may or may not be intense; depending on how well they are received by the audience.

The role of media in promoting such stereotyped images can be best explained by Dominick (2001) who cited the unquestionable persona of 'television' that it is not only capable of generating stereotypical imagery as it has a significant affect in changing them as well.

\section{Methodology}

This paper is based on the content analysis of Pakistani television commercials that run on Pakistani television channels. The study was aimed to investigate the female and male representations in Pakistani television commercials. For this purpose 25 commercials were randomly selected from four broad categories of household products, beauty products, telecommunications and edibles. These four product categories represent those television advertisements that have been given greater exposure (in terms of space allocated / air time) on Pakistani television channels and also enlist in top ten product category in the year 2008. The aforementioned top ten product category list was prepared by Gallup Pakistan and accessed from the Aurora purple book (Pakistani advertising magazine) published by Dawn group of newspapers in 2008. (Gallup Pakistan)

Definitions of the categories are as under:

- Household Products: The following category consists of those television commercials that feature products of every day consumption and hold significance for the entire family alike. These include: detergents, household appliances like washing machine, microwave, dish washing liquids etc.

- Health \& Beauty: This category encompasses those television commercials that feature products consumed for personal care and wellbeing. These include: beauty creams, antibacterial soaps, face wash, shampoos etc. 
- Telecommunication: The category covers the telecommunication service providing companies.

- Edibles: This category contains television commercials that feature food items including snacks, bakery items, kid's food, dairy products etc. These include: Bake parlor, Blue Band, Cerelac, Knorr, Olpers and Lu bakery biscuits.

The objectives of this study were set out to identify the gender representation of male and female in Pakistani television commercials; therefore male / female role portrayals, demographic focus and main voice over/ narrator was studied closely. Hence, these selected television commercials were placed in pre-defined and exclusive categories in order to analyze them in detail. These categories were designed primarily to examine the role portrayal of male $\&$ female characters in television commercials like for instance students, professional, family member, housewives, and friends. The dominant voice over by particular gender was also examined in detail. Due to the nature of these categories it was imperative to take the perspectives of neutral experts in order to reduce the possibility of subjectivity in analysis. Following discussion reflects the mutually agreed characteristic portrayals of male and female in Pakistani television commercials. In case of partial agreement for diverse options in the same category, researcher discretion was considered.

\section{Characteristic Portrayals:}

Categories for analyzing male and female characteristic portrayals in Pakistani television commercials are stated below:

\section{i. Supportive \& caring}

This category enlists individuals that are depicted as caring and supportive towards their families, by means of their behavior and attitude.

\section{ii. Conflicting}

This category enlists portrayal of male and female characters in a way that they have disagreement or conflicting ideas of life as compare to their counterparts.

\section{iii. Stylish \& glamorous}

This category enlists portrayal of male and female characters as a stylish and attractive personality by means of their physical appearance. This includes the way characters are spruced up in fashionable attire.

\section{iv. Simple}

This category enlists portrayal of male and female characters as a simple, modest and ordinary looking personality by means of their physical appearance. This includes the way characters are spruced up in casual attire.

\section{v. Confident}

This category enlists portrayal of male and female characters as a confident individual by means of their approach towards life. They are self aware people and understand their strengths and weaknesses. 


\section{vi. Nervous}

This category enlists portrayal of male and female characters as a problematic and panicky individual who can lose control from his nerves and get tense easily.

\section{vii. $\quad$ Funny / lively}

This category enlists portrayal of male and female characters that play folly acts and try to muck around in the entire commercial.

\section{viii. Serious}

This category enlists portrayal of male and female characters that have a serious outlook, thoughtful and handle different situations in modest way.

\section{ix. Any other}

This category is designed for individual traits that are not fit for any other category.

\section{Demographic focus:}

Together with these categories; demographic focus in the aforementioned 25 television commercials was also studied. For this reason, separate category for examining demographic focus in television commercials was designed.

In this context of study, demographic focus reflects the central focus on particular gender and age groups feature in television commercials. The prime emphasis of this research is on the male and female representation in Pakistani television commercials and only young to middle aged male and female role portrayals are studied. Hence categories are as follows:

i. male

ii. female

iii. combination (both male and female)

Main Voice over / Narrator This category was designed to analyze the gender of prime narrators and also to understand the ratio of male and female in leading voice over. Categories are as under:
i. Only Male
ii. Only Female
iii. Combination of i. (Only male) \& ii. (Only female)

\section{Review of Past Literature}

The relevant literature in the context of this study highlights the above mentioned aspects of gender imagery i.e. the percentage of female representation as compared to their male counterparts in televised advertisements, the main voice over narrator incorporated in television advertisements, the character portrayals of male and female, the situations in which male and female generally appear in most of Pakistani television advertisements.

Ahsltrand (2005) revealed that considerable amount of stereotypical portrayal seem evident in Austrian television commercials. Moreover, women were mostly given 
marginal coverage as compared to men in most of the Austrian television advertisements especially as main voice over / narrator and in dominant characters. Whereas men on the other hand were given dominant representation in terms of their role portrayals and they often featured in masculine products. Apart from that, women and men were equally given their due representation in characters portrayal i.e. in occupational and household settings both.

Holtzhausen, Jordaan \& North (2011) reflect that women are mostly depicted as product user as compare to sex objects in South African television commercials. Mostly female were incorporated in advertisements of personal care products in comparison to sports related products. Approximately $40 \%$ of television advertisements depicted women in them. Overall, women are not stereotyped in South African television commercials rather advertisers did make an effort to feature women in multifaceted role portrayals which ultimately reflects the image of modern South African women. Although women were frequently associated with products of personal care, food and household thereby relating women in low involvement decision making process. Ostensibly the role of spokesperson in television commercials appears significant as it serve as opinion leader for the masses. Hence female were given importance as opinion leaders who could affect masses decision making.

Espinar-Ruiz, González-Díaz (2012) asserted that the gender in-equal representation was obvious in voice over / narration in most of the Spanish television advertisements. Moreover, when it comes to health related claims and aesthetic attributes of the products; female voice over was mainly used. Similarly, male voice over was associated with the claims comprising of entertainment and special packages instead of product benefits. In order to understand the portrayal of male and female in terms of physical appearance, it is therefore noticeable that female have been given more beautiful exposure as compared to their male counterparts.

Shrikhande (2003) revealed that female characters were mostly depicted in young age group as compared to their male counterparts in Indian television advertisements. Ostensibly the reason for such youth full portrayal of female was obvious i.e. to attract the attention of viewers whereas males were significantly represented in middle aged and old characters thereby associating the image of a an experienced persona with them. Moreover, females were mainly featured in domestic setting whereas male in professional settings thereby emphasizing on the existing stereotype of society where the most suitable position for a female appeared to be her home. Voice over / off screen narrations were predominantly done by male as compared to female. Although gender equality was obvious in case of product representation as both male and female performed their role in the same way. Females were largely depicted as 'central figure' especially in household products. 
Duman, Yilmazel \& Akbulut (2013) revealed that the women were mostly associated with edible, household products; they were projected as house wife about $80 \%$ in Turkish television advertisements, a caregiver mother dedicated for the well being of her family. Moreover, physical attractiveness of women is also heavily focused. Professional character of women is not embedded in Turkish television advertisements. Voice over was mainly dominated by the representation of male as compared to females.

Wong \& Chan (2006) investigated the gender role and gender trait portrayal in children advertisements. Findings revealed that females were outnumbered in case of voice over / narrator. Similarly male were depicted in autonomous roles whereas females appeared to be indulged in relationship roles. Same goes with their traits, males were depicted in displaying anti social behaviors having an assertive attitude and energetic life style. On the other hand females were portrayed as care givers, reliant and work shy. Overall, traditional male dominated value portrayal seemed obvious assigning virtuous obligations for females.

\section{Presentation and Analysis of Data}

This study was based on the gender portrayals in Pakistani television commercials that run on Pakistani channels. Gender portrayals have always been an important social paradigm for social science scholars. Several research studies have been conducted on the representation of male and female in television commercials across the globe. It is therefore crucial for the researcher to investigate the dimensions of gender representation in our social context i.e. in relation to Pakistani television commercials.

As per findings of the study, following discussion is divided in few dimensions in order to analyze the major insights in detail.

\section{Cross tabulation of Gender and Main Voice Over / Narrator}

\begin{tabular}{|l|c|}
\hline \multicolumn{1}{|c|}{ Gender } & Voice Over \\
\hline Male & $40 \%$ \\
\hline Female & $28 \%$ \\
\hline Both (Male \& Female) & $32 \%$ \\
\hline Total & $100 \%$ \\
\hline
\end{tabular}

As per findings of the study, overwhelming representation of males (i.e. 40\%) in terms of voice over / narrator was observed. This result is consistent across past research studies whereby women seems outnumbered by their male counterparts when studied frequency of voice over / narrator in television commercials. 


\section{Cross Tabulation of Voice Over \& Product Category}

\begin{tabular}{|c|c|c|c|c|c|}
\hline Gender & Household & Health \& Beauty & Edibles & Telecom. & Total \\
\hline Male & $40 \%$ & $20 \%$ & $20 \%$ & $20 \%$ & $100 \%$ \\
\hline Female & $14 \%$ & $57 \%$ & $29 \%$ & $0 \%$ & $100 \%$ \\
\hline Both & $14 \%$ & $29 \%$ & $14 \%$ & $43 \%$ & $100 \%$ \\
\hline
\end{tabular}

Male voice over / narrators were mostly used in the category of household products (40\%) followed by edibles, health and beauty and telecommunication respectively. Considerable representation of female voice over mostly found in health and beauty (57\%) which confirms the existing stereotypical portrayal of female in personal care and aesthetic products.

\section{Cross Tabulation of Gender \& Demographic Focus In Pakistani Television Commercials}

\begin{tabular}{|l|c|}
\hline \multicolumn{1}{|c|}{ Age Group } & Demographic Focus \\
\hline Minors / Kids & $8 \%$ \\
\hline Adult Male & $8 \%$ \\
\hline Adult Female & $24 \%$ \\
\hline Combination & $32 \%$ \\
\hline Family & $28 \%$ \\
\hline Total & $100 \%$ \\
\hline
\end{tabular}

Results reveal that females were centrally focused in terms of individual portrayal as compared to their male counterparts. Their central figure position equally appears significant when they dominate the commercial independently or as active member of family. Men and children were marginally depicted individually in the television commercials in the context of this study. Apart from that men appeared as supporting family members in domestic setting or a helpful stranger in outside context of communication. In addition to this, combination (32\%) and family (28\%) group reflects the collective portrayal of various age groups.

4. Cross Tabulation of Gender \& Demographic Focus With Respect To Product Category

\begin{tabular}{|c|c|c|c|c|c|}
\hline Gender & Household & Health \& beauty & Edibles & Telecom. & Total \\
\hline Male & $0 \%$ & $50 \%$ & $0 \%$ & $50 \%$ & $100 \%$ \\
\hline Female & $17 \%$ & $83 \%$ & $0 \%$ & $0 \%$ & $100 \%$ \\
\hline Both & $14 \%$ & $14 \%$ & $14 \%$ & $58 \%$ & $100 \%$ \\
\hline
\end{tabular}

Category of edibles and household reflected the interesting turn where by men and women both were given equal representation and it can be asserted that the role of family 
appears crucial when it comes to the promotion of such products. Gender portrayal in telecommunication products reflects the over domination of male i.e. 50\% in comparison with female $0 \%$ (on individual basis). Similarly health and beauty category shows women with $83 \%$ share outnumbering their male counterparts.

\section{Cross Tabulation of Gender \& Characteristic Portrayals}

\begin{tabular}{|c|c|c|}
\hline Characteristics & Male & Female \\
\hline Supporting \& Caring & $26 \%$ & $40 \%$ \\
\hline Conflicting & $0 \%$ & $0 \%$ \\
\hline Stylish \& Glamorous & $11 \%$ & $28 \%$ \\
\hline Simple & $26 \%$ & $12 \%$ \\
\hline Confident & $7 \%$ & $4 \%$ \\
\hline Nervous & $0 \%$ & $4 \%$ \\
\hline Funny / Lively & $0 \%$ & $0 \%$ \\
\hline Serious & $0 \%$ & $4 \%$ \\
\hline No Portrayal & $30 \%$ & $8 \%$ \\
\hline Total & $100 \%$ & $100 \%$ \\
\hline
\end{tabular}

Females were mostly depicted in the characters of supporting and caring 40\%, stylish / glamorous $28 \%$ and simple women with $12 \%$. The following analysis of commercials also supports the notion that female gender portrayal still exist and the stereotypical idea mostly projected women as primary care giver, centre of attention and a responsible decision maker who's prime focus is of giving comfort and assistance to their families.

Males were mostly appeared in supportive / caring, simple as $26 \%$ respectively and stylish characters with $11 \%$. Moreover, findings from the category of 'no portrayal' highlight that the ratio of less significant character portrayal seems common for male as compared to females.

\section{Gender Association with Product Categories:}

i. Characteristics Portrayal of Male With Respect To Product Category

\begin{tabular}{|l|c|c|c|c|}
\hline \multicolumn{1}{|c|}{ Characteristics } & Household & Health & Edible & Telecom \\
\hline Supportive \& caring & $16 \%$ & - & $4 \%$ & $8 \%$ \\
\hline Conflicting & - & - & - & - \\
\hline Stylish \& glamorous & - & $8 \%$ & - & $4 \%$ \\
\hline Simple & $8 \%$ & - & $12 \%$ & $8 \%$ \\
\hline Confident & - & - & $4 \%$ & $4 \%$ \\
\hline Nervous & - & - & - & - \\
\hline Funny / lively & - & - & - & - \\
\hline Serious & - & - & - & - \\
\hline No portrayal & $4 \%$ & $20 \%$ & $8 \%$ & - \\
\hline
\end{tabular}


As per findings of the above mentioned table, it seems obvious that men were mostly depicted as supportive and caring in the category of household with $16 \%$, telecom $8 \%$ and edibles $4 \%$. Simple characters mostly observed in the commercials of edible $12 \%$, telecommunication and household $8 \%$ respectively. Overall male characters were represented dominantly as supportive, caring and simple individuals.

\section{ii. Characteristics Portrayal of Female With Respect To Product Category}

\begin{tabular}{|c|c|c|c|c|}
\hline Characteristics & Household & Health & Edible & Telecom. \\
\hline Supportive \& Caring & $20 \%$ & - & - & - \\
\hline Conflicting & - & - & - & - \\
\hline Stylish \& Glamorous & - & $20 \%$ & $4 \%$ & $4 \%$ \\
\hline Simple & - & $4 \%$ & - & $8 \%$ \\
\hline Confident & - & $4 \%$ & - & - \\
\hline Nervous & - & $4 \%$ & - & - \\
\hline Funny / Lively & - & - & - & - \\
\hline Serious & - & - & - & $4 \%$ \\
\hline No Portrayal & - & $4 \%$ & - & $4 \%$ \\
\hline
\end{tabular}

Findings of this study explained that women are mostly associated with the products of personal care and aesthetic products with the highest share among the rest. Also, men were not given due emphasis in any product category especially in individual case but they got considerable count as family member especially in the category of edibles and household. These findings were partially supported by previous researches.

\section{Conclusions}

This research encapsulates the idea of stereotypical gender portrayal in television commercials particularly in case of female portrayal. Considering the characteristic portrayal of male and female in Pakistani television advertisement, a monotonous approach towards both gender and their related responsibilities has been observed.

"Gender is one of the most studied social paradigms as it is the main paradigm that people use in determining how to act and interact with others"(Hooper, 2013). These generalized images do exist today and will continue to grow if no significant measures will be taken to minimize biased gender imagery. Also, this unequal representation reflects the subjective approach of media professionals towards the society at large.

There are certain deeply penetrated social generalizations about the 'expected role of men \& women' as a member of any particular society. Women have long been associated with 
the most familiar 'social tags' that they should be an ideal wife, dedicated and self less housewife, friendly sister, a caring mother and understanding daughter. Hence women or in other words an ideal feminine 'self' should possess 'all in one' traits in order to please all the people around her. Interestingly such kind of images have almost equally presented in television commercials across several studies.

In view of the aforementioned dimensions, it can be asserted that women are still deemed as care givers and depicted in situations whereby female appears to be serving voluntarily to their families whereas men enjoys their independent and autonomous position. Results of this study and the past literature are consistent in this context of the study. Voice over / narrators generally define a person responsible enough and possess authority to manipulate consumer minds by acting as credible source or opinion leader for masses. According to the findings, above stated stereotypical role also exists in Pakistani television advertisements. It can also be asserted that the reason behind these stereotypical portrayals might also be the values and beliefs that exist within the framework of a particular society. As Craig (1990) cited that: "advertisers manipulate gender stereotypes according to economic considerations, exploiting whichever gender images best fit the product offered and the audience targeted."

Ostensibly women have always been criticized for aspiring beauty and acquiring personal care products; on the contrary men would be interested in latest technological gadgets, automobiles, housing and other high involvement decisions. It can be asserted from the values and beliefs deeply penetrated in our social context that there are certain parameters that we generally would like to follow. It was crucial for the researcher to investigate whether such indifferent behavior and biased approach prevailed in Pakistani advertising landscape or not. Moreover, attempt was made to explore the amount of gender imagery depicted in Pakistani commercials.

The findings of this study also reveal that few emerging trends have been added in the context of male portrayals in television commercials. Previously, research studies observed men in the authoritative and domineering roles whereas the findings of this study seem inconsistent across past investigations. Contemporary advertising primarily television commercials tend to depict men in supportive and caring roles, contributing in the domestic responsibilities. For instance: example of Jazz commercial (telecommunication service), whereby a son is taking care of his father and appears in supportive and caring role. This type of role portrayals should be further endorsed in Pakistani television commercials as it induces positive feelings and may change people's attitude and behavior altogether. As Valerie Hooper (2008) rightly asserted that: "Television commercials are capable of influencing viewers' beliefs about what exists, what is normal, what is right, and how they should behave within their gender." 
Whether it's a matter of choosing healthy cooking oil, dairy product or household cleaning detergents their role in proving maximum results seems inevitable. All in all women serve as an essential source of giving unlimited care, comfort and affection. As Shrikhande (2003) indicated that the women are still predominantly associated with household products in many television commercials. Apart from that, women are also increasingly being portrayed as central figures in the personal hygiene products category. Wong \& Chan (2006) also revealed that females were portrayed as care givers, reliant and work shy in television commercials of Mainland China.

On the basis the findings of this research, it is observed that males were predominantly used in voice over / narration as compared to females. Females were mostly associated with personal care and household products, thereby assigning low involvement decisions primarily. Males were mostly portrayed in professional setting in turn promoting the existing stereotypical images of dominant and independent position of male. Females were largely depicted in domestic setting consequently assigning them the image of caregivers, relationship oriented, central figure in household setting and dependent self. This was evident from the female depiction in household products advertisement typically.

Interestingly, a social stigma or rather a strong prejudice reflecting the image of men as a care free, independent and dominant actor prevails in our social fabric. This study revealed that this 'social stigma' seems to be shattered at least to an extent in the context of Pakistani television commercials. Although, their authority and dominance still exist when you look at the overwhelming count of men as voice over / narrators in Pakistani television advertisements.

On the contrary; supportive / caring and simple characteristics portrayal reflects the softer and humble image of men which is not congruent with few past research studies. In view of previous researches, men were predominantly featured as dominant, independent individual, mostly placed in professional setting; thereby highlighting their domineering image. But the Ahsltrand (2005) findings did not seems compatible with the early studies as it revealed that women and men were equally given their due representation in characters portrayal i.e. in occupational and household settings both.

At present, men are also depicted in domestic setting, extending their help for domestic chores and nurturing their child equally with their female counterparts primarily in this context of research. This finding appears congruent with the findings of Ahsltrand (2005) but at the same time against the findings of Valerie Hooper (2008): "Men are more likely to be depicted working and at work or other "non-home" locations. Women appear less often in television commercials, are more likely to be representatives of domestic products, performing domestic tasks, and in a home setting." 
Apparently, this is the point of change that will bring an interesting paradigm shift in terms of gender image portrayal in Pakistani media landscape. Moreover, equal representation was observed in terms of gender portrayal with respect to telecommunication services. There was no specific monopoly of any particular gender in this product category.

Considering the findings of this study, overwhelming male representation is substantially evident in terms of their dominating voice overs. This finding is also similar with previous research studies by Duman, Yllmazel \& Akbulut (2013) revealed that voice reflects the dominant representation of men in comparison with women in Turkish television advertisements. Espinar-Ruiz, González-Díaz (2012) male voice over was mostly associated with the claims of entertainment and special packages instead of product benefits. Ahsltrand (2005) also supported the male domination in terms of their role portrayals and they often featured in masculine products.

Thus, it can be asserted that stereotypical portrayals in television commercials still persist and have always been a matter of intense debate. Considering the aforementioned discussion on the stereotypical gender imagery in television advertisements it is evident that few commonly featured role portrayals are prevalent in different regions of the world. It is imperative to understand that these gender biased media representations can affect the thinking and lifestyle of mass audience. There is a great saying: 'with great power comes great responsibility'; so it is the fundamental duty of media practitioners to critically analyze the media content before they make it accessible for the audience and create their messages accordingly in order to reduce the gender discrimination through their media portrayals.

\section{References}

Ahsltrand, Marie. (2007). Thesis. Gender stereotyping in television advertisements_ A case of Austrian state television. Retrieved. 19 May 2013. From http://epubl.ltu.se/1402-1773/2007/236/LTU-CUPP-07236-SE.pdf

Broadbent, Simon. (1979). Spending Advertising Money, $3^{\text {rd }}$ Edition. Random House Business Books.

Callan, Victor J., Gallois, Cynthia., Noller, Patricia., \& Kashima, Yoshihisa. (1999). Social Psychology, $2^{\text {nd }}$ Edition, Sydney: Harcourt Australia Pty Limited.

Craig, R. (1990, December). A content analysis comparing gender images in network television commercials aired in daytime, evening, and weekend telecasts. (ERIC 
Document Reproduction Service Number ED 329 217.) Retrieved.28 April2013. Retrieved from, http://humboldtcollege.wikispaces. comfileviewmensmen.pdf

Dominick, Joseph R. (2001). The Dynamics of Mass Communications-----Media in the Digital Age, $7^{\text {th }}$ edition. London: McGraw Hill.

Duman, Nuriye Büyükkayac1., Yılmazel, Gülay., Akbulut, A. Burcu. (2013). The Effect of Cultural Changes to Woman Image in Advertisements in Turkish Televisions. II. International Conference on Communication, Media, Technology and Design, 02-04 May 2013, Famagusta - North Cyprus. Retrieved from: httpwww.cmdconf.net2013makalePDF54.pdf

Espinar-Ruiz, Eva., \& González-Díaz, Cristina. (2012). Gender portrayals in food commercials: A content analysis of Spanish television advertisements. Observatorio (OBS*) Journal, vol.6, No.4 (2012), 109-126, Retrieved on 19 May 2013. Retrieved from: http:// obs.obercom.ptindex.phpobsarticledownload586540

Frith, Katherine Toland \& Mueller, Barbara. (2010). Advertising and Societies Global Issues, $2^{\text {nd }}$ Edition, New York: Peter Lang Publishing Inc.

Gallup Pakistan. (2008). TV Ad Spend (Five year trend 2002- 2007). Aurora The Purple Book A Dawn Media Group Publication on Ideas and Marketing Approaches, 40

Giddens, Anthony. (2006). Sociology. Oxford: Polity Press.

Hayes, Nicky. (1996). Foundations of Psychology. An Introductory Text. UK: Thomas Nelson \& Sons Ltd.

Holtzhausen, T., Jordaan, Y., North, E.J. (2011). The portrayal of women in South African television commercials, Southern African Business Review Volume 15 Number 3 2011, Retrieved 19 May 2013, Retrieved from. http://www.ajol.info/index.php/sabr/article/viewFile/76410/66868

Hooper, Valerie. (2008, April 30). Thesis Portrayals of Gender in Television Commercials and the Effects on Achievement Aspirations of Audiences, Retrieved on 19 May 2013. Retrieved from, httpwww.unh.edusociologymediapdfsjournal2008HooperEDITED.pdf

Lefrancois, Guy R. (2000). Theories of Human Learning, $4^{\text {th }}$ Edition, California: Wadsworth / Thomson Learning. 
Mahsud, Muhammad Nawaz. (2006). Mass Communication: An Introduction to Information Revolution, Theories, Skills and Practices. Islamabad: D.G. Administration, Higher Education Commission.

McQuail, Denis. (2005). McQuail's Mass Communication Theory, $5^{\text {th }}$ Edition, New Delhi: Vistaar Publications, A division of Sage Publications India.

Price, Stuart. (1998) Media Studies, $2^{\text {nd }}$ Edition, Essex England: Addison Wesley Longman Limited.

Shrikhande, Vaishali. (2003) Stereotyping Of Women in Television Advertisements (Thesis) Louisiana Sate University and Agricultural and Mechanical College, Retrieved on 19 July 2013, Retrieved from, http://etd.lsu.edu/docs/available/etd0516103-141609/unrestricted/Shrikhande_thesis.pdf

White, Roderick. (2000). Advertising $4^{\text {th }}$ Edition, Berkshire, McGraw Hill Publishing Company.

Wong, Krystie., \& Chan, Kara. (2006). A gender portrayal of children's television commercials in mainland, International Advertising and Communication, 2006, 319-341. Doi: 10.1007/3-8350-5702-2_17

Wood, Julia T. (1997). Gendered Media: The Influence of Media on Views of Gender. Annual Editions: Mass Media 97 / 98.

\section{Bibliography}

Broadbent, Simon. (1979). Spending Advertising Money, $3^{\text {rd }}$ Edition. Random House Business Books.

Callan, Victor J., Gallois, Cynthia., Noller, Patricia., \& Kashima, Yoshihisa. (1999). Social Psychology, $2^{\text {nd }}$ Edition, Sydney: Harcourt Australia Pty Limited.

Dominick, Joseph R. (2001). The Dynamics of Mass Communications-----Media in the Digital Age, $7^{\text {th }}$ edition, London: McGraw Hill.

Frith, Katherine Toland \& Mueller, Barbara. (2010). Advertising and Societies Global Issues, $2^{\text {nd }}$ Edition, New York: Peter Lang Publishing Inc.

Gallup Pakistan. (2008). TV Ad Spend (Five year trend 2002- 2007). Aurora The Purple Book A Dawn Media Group Publication on Ideas and Marketing Approaches, 40 
Giddens, Anthony. (2006). Sociology. Oxford: Polity Press.

Hayes, Nicky. (1996). Foundations of Psychology, An Introductory Text. UK: Thomas Nelson \& Sons Ltd.

Lefrancois, Guy R. (2000). Theories of Human Learning, $4^{\text {th }}$ Edition, California: Wadsworth / Thomson Learning.

Mahsud, Muhammad Nawaz. (2006). Mass Communication: An Introduction to Information Revolution, Theories, Skills and Practices. Islamabad: D.G. Administration, Higher Education Commission.

McQuail, Denis. (2005). McQuail's Mass Communication Theory, $5^{\text {th }}$ Edition, New Delhi: Vistaar Publications, A division of Sage Publications India.

Price, Stuart. (1998) Media Studies, 2 ${ }^{\text {nd }}$ Edition, Essex England: Addison Wesley Longman Limited.

White, Roderick. (2000). Advertising $4^{\text {th }}$ Edition, Berkshire, McGraw Hill Publishing Company.

Wood, Julia T. (1997). Gendered Media: The Influence of Media on Views of Gender. Annual Editions: Mass Media 97 / 98.

\section{Webliography}

Ahsltrand, Marie. (2007). Thesis. Gender stereotyping in television advertisements_ A case of Austrian state television. Retrieved. 19 May 2013. From http://epubl.ltu.se/1402-1773/2007/236/LTU-CUPP-07236-SE.pdf

Craig, R. (1990, December). A content analysis comparing gender images in network television commercials aired in daytime, evening, and weekend telecasts. (ERIC Document Reproduction Service Number ED 329 217.). Retrieved. 28 April 2013. Retrieved from. httphumboldtcollege.wikispaces.comfileviewmensmen.pdf

Duman, Nuriye Büyükkayac1., Y1lmazel, Gülay., Akbulut, A. Burcu. (2013). The Effect of Cultural Changes to Woman Image in Advertisements in Turkish Televisions. II. International Conference on Communication, Media, Technology and Design, 02-04 May 2013, Famagusta - North Cyprus. Retrieved from: httpwww.cmdconf.net2013makalePDF54.pdf 
Espinar-Ruiz, Eva., \& González-Díaz, Cristina. (2012). Gender portrayals in food commercials: A content analysis of Spanish television advertisements. Observatorio (OBS*) Journal, vol.6, No.4 (2012), 109-126. Retrieved. 19 May 2013. Retrieved from: http:// obs.obercom.ptindex.phpobsarticledownload586540

Holtzhausen, T., Jordaan, Y., North, E.J. (2011). The portrayal of women in South African television commercials. Southern African Business Review Volume 15 Number 3 2011. Retrieved. 19 May 2013. Retrieved from. http://www.ajol.info/index.php/sabr/article/viewFile/76410/66868

Hooper, Valerie. (2008, April 30). Thesis. Portrayals of Gender in Television Commercials and the Effects on Achievement Aspirations of Audiences. Retrieved. 19 May 2013. Retrieved from. httpwww.unh.edusociologymediapdfsjournal2008HooperEDITED.pdf

Shrikhande, Vaishali. (2003) Stereotyping Of Women in Television Advertisements (Thesis). Louisiana Sate University and Agricultural and Mechanical College. Retrieved. 19 July 2013. Retrieved from. http://etd.lsu.edu/docs/available/etd0516103-141609/unrestricted/Shrikhande_thesis.pdf

Wong, Krystie., \& Chan, Kara. (2006). A gender portrayal of children's television commercials in mainland. International Advertising and Communication, 2006, 319-341. Doi: 10.1007/3-8350-5702-2_17

Sara Wahid is Research Scholar in the Department of Mass Communication, University of Karachi.

Dr. Aazadi Fateh Muhammad is Assistant Professor in the Department of Mass Communication, Federal Urdu University for Arts, Science \& Technology.

Dr. Fateh Muhammad Burfat is Professor and Chairman in the Department of Criminology, University of Karachi. 